\section{Effects of Foliar Potassium Fertilization on Fruit Growth Rate, Potassium Accumulation, Yield, and Quality of 'Kousui' Japanese Pear}

\author{
Changwei Shen, Yifei Ding, Xiqiong Lei, Peng Zhao, Shuo Wang, \\ Yangchun Xu, and Caixia Dong ${ }^{1}$
}

Additional Index wORDs. Pyrus pyrifola, sugar, organic acid, amino acid

SUMMARY. A field experiment was conducted over three growing seasons (2012-14) to study the effect of the foliar application of different potassium $(\mathrm{K})$ fertilizers [potassium phosphate monobasic $\left(\mathrm{KH}_{2} \mathrm{PO}_{4}\right)$, potassium nitrate $\left(\mathrm{KNO}_{3}\right)$, and humic acid potassium (HAK)] on the fruit growth rate, yield, and quality of 'Kousui' japanese pear (Pyrus pyrifola) trees. Except the first year of study, foliar application of $\mathrm{K}$ fertilizers generally led to an increase in the concentration of fruit total soluble sugar, titratable acidity (TA) and sweetness, along with an elevated $\mathrm{K}$ accumulation in leaf and fruit at maturity. In 2013 and 2014, compared with the control, $\mathrm{KNO}_{3}$ treatment led to an average $16 \%$ higher yield, and $\mathrm{HAK}$ led to an average $15 \%$ higher soluble solid content (SSC). Furthermore, HAK resulted in $26 \%$ higher yield in $2014 . \mathrm{KNO}_{3}$ treatment showed $19 \%$ higher leaf $\mathrm{K}$ concentration, $38 \%$ leaf $K$ accumulation, and $43 \%$ fruit $K$ accumulation in maturity than the control in 2014. Different effects were found on the concentration of specific types of sugar and organic acid, of which fructose and malate were consistently increased by the $\mathrm{K}$ application. With regard to the amino acids, $\mathrm{KNO}_{3}$ and $\mathrm{HAK}$ treatments led to a significant increase in the concentration of aspartic acid, which was $12 \%$ and $22 \%$ higher than the control, respectively. In conclusion, foliar application of $\mathrm{KNO}_{3}$ is an efficient way to increase 'Kousui' japanese pear fruit yield, whereas spraying HAK is an effective way to improve the fruit quality.

J apanese pear is one of the leading cultivated fruit trees in temperate regions. After apple (Malus xdomestica) and citrus (Citrus sp.), it is the third largest fruit species in China, both in planting areas and fruit yield. As the top producing country, China grows more than $60 \%$ of the world pear (Pyrus sp.) production (Boyer et al., 1943; Wu et al., 2013). $\mathrm{K}$ is highly mobile in plants and constitutes up to $10 \%$ of plant dry weight (Adams and Shin, 2014; Shin, 2014; Walker et al., 1996). Regarding the total amount of mineral nutrients required by plants, potassium is required in the largest amount after nitrogen (N) (Zörb et al., 2014); moreover, it is the largest nutrient

Key Laboratory of Plant Nutrition and Fertilization in Low-Middle Reaches of the Yangtze River, Ministry of Agriculture/Jiangsu Key Laboratory of Solid Organic Waste Utilization/Jiangsu Collaborative Innovation Center for Solid Organic Waste Resource Utilization/College of Resources and Environmental Science, Nanjing Agricultural University, Nanjing 210095 , China

This research was supported by the Special Fund for Agro-scientific Research in the Public interest (201203013) and China Agriculture Research System (CARS-29-15).

${ }^{1}$ Corresponding author. E-mail: cxdong@njau.edu. $\mathrm{cn}$. required by the fruit (Lester et al., 2006; Mpelasoka et al., 2003). K activates numerous enzymes, which are critical for various metabolic proand transformation of sugar and starch araldi et al., 1991; Karley and White, 09; Lester et al., 2010a; Niu et al. 2013; Römheld and Kirkby, 2010). Furthermore, $\mathrm{K}$ is an essential nutrient involved in the phloem translocation cesses, such as biosynthesis, transport of assimilates, including sucrose movement from shoot to root and to sink tissues such as fruit (Lebaudy et al., 2007). It is generally considered as a quality element, which could increase fruit development with higher quality and longer shelf life by enhancing synthesis and translocation of carbohydrates in plants (Niu et al., 2008). For example, the fruit of 'Kinnow' mandarin (Citrus deliciosa $\times$ Citrus nobilis) became larger and harder with increasing $\mathrm{K}$ supply. In contrast, the number of fruit cells, fruit size, and the SSC were significantly reduced by $\mathrm{K}$ deficiency (Ashraf et al., 2010).

In our previous research, we found that fruit $\mathrm{K}$ concentration decreased sharply with the increase of fruit size during expansion stage to maturation, which suggested that strong $\mathrm{K}$ supply was demanded by fruit. Balanced fertilization is an efficient measure to increase the yield and quality of 'Kousui' japanese pear. However, compared with the amount of $\mathrm{N}$ and phosphorus $(\mathrm{P})$ input to the 'Kousui' japanese pear orchard, the supply of K was found to be seriously insufficient. Foliar fertilization was proved to be an efficient way to supplement the nutrients that the plant needed. It is a well-established measure for timely supplement of $\mathrm{K}$ to increase yields, fruit size, fruit volume, SSC, and sugar/acid ratio of 'Gala' apple (Reuveni et al., 1998a), 'Valencia' sweet orange [Citrus sinensis (Calvert and Smith, 1972)], and 'Williams' european pear [Pyrus communis (Hudina and Stampar, 2002)]. $\mathrm{KH}_{2} \mathrm{PO}_{4}$ (Reuveni et al., 1998b), potassium sulphate

\begin{tabular}{llll}
\hline $\begin{array}{l}\text { Units } \\
\text { To convert U.S. to SI, } \\
\text { multiply by }\end{array}$ & U.S. unit & SI unit & $\begin{array}{l}\text { To convert SI to U.S., } \\
\text { multiply by }\end{array}$ \\
\hline 29,574 & $\mathrm{fl} \mathrm{oz}$ & $\mu \mathrm{L}$ & $3.3814 \times 10^{-5}$ \\
29.5735 & $\mathrm{fl} \mathrm{oz}$ & $\mathrm{mL}$ & 0.0338 \\
0.3048 & $\mathrm{ft}$ & $\mathrm{m}$ & 3.2808 \\
3.7854 & $\mathrm{gal}$ & $\mathrm{L}$ & 0.2642 \\
2.54 & inch $(\mathrm{es})$ & $\mathrm{cm}$ & 0.3937 \\
25.4 & inch(es) & $\mathrm{mm}$ & 0.0394 \\
6.4516 & inch ${ }^{2}$ & $\mathrm{~cm}$ & 0.1550 \\
0.4536 & $\mathrm{lb}$ & $\mathrm{kg}$ & 2.2046 \\
1.1209 & $\mathrm{lb} / \mathrm{acre}$ & $\mathrm{kg} \cdot \mathrm{ha}^{-1}$ & 0.8922 \\
1 & $\mathrm{micron}(\mathrm{s})$ & $\mu \mathrm{m}$ & 1 \\
28.3495 & $\mathrm{oz}$ & $\mathrm{g}$ & 0.0353 \\
0.1 & $\mathrm{ppm}$ & $\mathrm{mg} / 100 \mathrm{~g}$ & 10 \\
0.001 & $\mathrm{ppm}$ & $\mathrm{mg} \cdot \mathrm{g}^{-1}$ & 1000 \\
1 & $\mathrm{ppm}$ & $\mathrm{mg} \cdot \mathrm{kg}^{-1}$ & 1 \\
1 & $\mathrm{ppm}$ & $\mathrm{mg} \cdot \mathrm{L}^{-1}$ & 1 \\
6.8948 & $\mathrm{psi}$ & $\mathrm{kPa}$ & 0.1450 \\
2.2417 & ton $(\mathrm{s}) / \mathrm{acre}$ & $\mathrm{t} \cdot \mathrm{ha}$ & 0.4461 \\
$\left({ }^{\circ} \mathrm{F}-32\right) \div 1.8$ & ${ }^{\circ} \mathrm{F}$ & ${ }^{\circ} \mathrm{C}$ & $\left({ }^{\circ} \mathrm{C} \times 1.8\right)+32$ \\
& & & \\
\hline
\end{tabular}


[ $\mathrm{K}_{2} \mathrm{SO}_{4}$ (Sing and McNeil, 1992)], $\mathrm{KNO}_{3}$ (Mukadam and Haldankar, 2012), potassium chloride [ $\mathrm{KCl}$ (Gill et al., 2005)], and potassium-complex humic acid (Shahryari et al., 2009) have been commercially used in various crops, of which $\mathrm{KH}_{2} \mathrm{PO}_{4}$ is routinely used as a foliar fertilizer since it contains both $\mathrm{P}$ and $\mathrm{K} . \mathrm{KCl}$ is the major source of $\mathrm{K}$ and usually cheaper than other $\mathrm{K}$ sources. However, since it involves chloride ion $\left(\mathrm{Cl}^{-}\right)$, it is generally not recommended on fruit trees and $\mathrm{Cl}^{-}$sensitive crop. $\mathrm{KNO}_{3}$ is full of ambiguity that, on one hand, it could supply $\mathrm{K}$ and nitrate $\left(\mathrm{NO}_{3}{ }^{-}\right)$simultaneously to plants which benefits the fruit development, and avoid $\mathrm{NO}_{3}{ }^{-}$leaching from soil compared with soil application of $\mathrm{N}$ (Dong et al., 2005); on the other hand, the foliar application of $\mathrm{NO}_{3}{ }^{-}$easily led to negative effects on fruit quality and even postharvest problems for some fruit, such as muskmelon (Cucumis melo), whose SSC and firmness were decreased by foliar application of $\mathrm{KNO}_{3}$ (Jifon and Lester, 2009). However, when applied to mango (Mangifera indica) trees, higher SSC, less TA, and less firmness was found (RebolledoMartínez et al., 2008). These inconsistent results might be related to the spraying time, application rate, and fruit species. Fructose, glucose, sorbitol, and sucrose are the main sugar types, and malate was the main organic acid produced in 'Huanguan' chinese white pear fruit [Pyrus bretschneideri (Song et al., 2012)]. Less attention was paid to the effects of $\mathrm{K}$ concentration and accumulation in 'Kousui' japanese pear leaf and fruit by the foliar application of different $\mathrm{K}$ sources, as well as the quality characteristics of 'Kousui' japanese pear fruit, such as various sugars, organic acids, and amino acids. The aim of this study was to evaluate the effect of different foliar application strategies of $\mathrm{K}$ fertilizers so as to provide a recommendation to growers on how to efficiently increase yield and improve fruit quality.

\section{Materials and methods}

Plant material and treatment.

The trials were conducted over three successive growing seasons on 10 -yearold scaffolding 'Kousui' japanese pear trees in an orchard from 2012 to 2014 . The orchard was located in the town of Ersheng in the city of Jurong city, Jiangsu Province, China. Trees were on callery pear (Pyrus calleryana) seedling rootstock planted at $4 \times 4 \mathrm{~m}$. Soil samples were taken from the soil surface $0-30 \mathrm{~cm}$ in Fall 2011 and were determined with the following chemical characteristics (Wells, 2009): $\mathrm{pH}$ $5.76,1.16 \%$ organic matter, 69.37 $\mathrm{mg} \cdot \mathrm{kg}^{-1}$ available $\mathrm{N}, 11.16 \mathrm{mg} \cdot \mathrm{kg}^{-1}$ available $P$, and $151.93 \mathrm{mg} \cdot \mathrm{kg}^{-1}$ available $\mathrm{K}$. The soil fertility was comparatively low. Each tree around the drip line in the orchard was supplied by $40 \mathrm{~kg}$ commercial organic fertilizer $(45 \%$ organic matter and $2 \mathrm{~N}-0.4 \mathrm{P}-$ $1.7 \mathrm{~K}), 2 \mathrm{~kg}$ cooked soybean (Glycine max), $2 \mathrm{~kg}$ calcium magnesium phosphate, and $0.75 \mathrm{~kg} \mathrm{~K}_{2} \mathrm{SO}_{4}$ in the base fertilization, $0.25 \mathrm{~kg} \mathrm{~K}_{2} \mathrm{SO}_{4}$ after anthesis, and $0.25 \mathrm{~kg}$ urea after fruit harvest.

Four treatments were applied to the same set of trees for 3 years. Three uniform trees were selected as a replicate, for a total of three replicates per treatment. Three foliar K sources $\left[\mathrm{KH}_{2} \mathrm{PO}_{4}, \mathrm{KNO}_{3}\right.$, and HAK (Foliwell ${ }^{\circledR} \mathrm{K}$; Omex, London, UK)], which contained $0.08 \% \mathrm{~K}$ were administered as follows: $0.3 \% \mathrm{KH}_{2} \mathrm{PO}_{4}, 0.22 \%$ $\mathrm{KNO}_{3}, 0.27 \% \mathrm{HAK}$, and water as control. HAK was a new-style liquid $\mathrm{K}$ fertilizer made by special organic compounds chelating $\mathrm{K}$ and no hormone was included. The foliar fertilizers were applied three times (27 Apr., 19 June, and 11 July) on a sunny day between 1500 and 1700 Hr. Each tree was sprayed $2 \mathrm{~L}$ liquid fertilizer with $0.1 \%$ surfactant with Tween ${ }^{\circledR} 20$ (Sigma-Aldrich, St. Louis, MO). The phenology of 'Kousui' japanese pear in 2013 and 2014 were both as follows: full of blossom (3 Apr.), young fruit stage (27 Apr.), expansion phase I (3 June), expansion phase II (2 July), maturity (6 Aug.), 1 month after harvest (8 Sept.), 2 months after harvest (10 Oct.), and leaf abscission (4 Nov.). The phenology of 'Kousui' japanese pear in 2012 was 1 week later than that in 2013 and 2014.

SoIl CHEMICAL PARAMETERS. The $\mathrm{pH}$ was determined using $1: 2.5$ $(\mathrm{w} / \mathrm{v})$ soil:water extracts. Alkalihydrolysable $\mathrm{N}$ was determined by the method used by $\mathrm{Lu}$ (1999). Available phosphorus was measured using extracts of hydrochloric acidammonium fluoride $\left[\mathrm{HCl}-\mathrm{NH}_{4} \mathrm{~F}\right.$ (Horta and Torrent, 2007)]. Available potassium was determined by extracting the soil with $1 \mathrm{~mol} \cdot \mathrm{L}^{-1}$ ammonium acetate $\left(\mathrm{CH}_{3} \mathrm{COONH}_{4}\right)$, and then measured by flame photometry (Allen et al., 1974). All extractions were performed in triplicate. The analysis values from the triplicate extractions were averaged before statistical analysis was performed.

Fruit SAMPle. In 2012-14, 30 'Kousui' japanese pear fruit were collected per tree at maturity stage and weighed. Fruit firmness was assessed with a penetrometer (FT327; Effegi, Alfonsine, Italy) with an $11.3-\mathrm{mm}$ probe. SSC was determined using a refractometer (PAL-1; Atago, Tokyo, Japan). Total soluble sugar was measured using the anthrone-sulphuric acid colorimetric method (Alexander and Edwards, 2003). TA was determined using standard acid-base titration (Sánchez, 2015).

In 2013 growing season, to evaluate the foliar $\mathrm{K}$ fertilizers on fruit growth rate and $\mathrm{K}$ concentration in fruit and leaves during the fruit development, eight fruits were randomly picked from four orientations on 27 Apr., 3 June, 2 July, and 6 Aug. At the same time, eight mature leaves from the midportion of the bearing branch of every tree were collected. In addition, leaves were also collected on 6 Sept., 6 Oct., and 4 Nov., respectively. After weighing the fruit, one quarter of these fruit were randomly selected, homogenized, and thoroughly dried. Leaves were rinsed twice with tap water and twice with deionized water, wiped with a paper towel, and thoroughly dried. Fruit and leaf samples were digested with a sulfuric acid-hydrogen peroxide $\left(\mathrm{H}_{2} \mathrm{SO}_{4}-\mathrm{H}_{2} \mathrm{O}_{2}\right)$ assimilating method in a digestion furnace $\left(280^{\circ} \mathrm{C}\right.$, $2 \mathrm{~kW}, \mathrm{l} \mathrm{h}$ ), and $\mathrm{K}$ concentration was determined by a flame photometer (AP1200; Aopu Analytical Instruments, Shanghai, China).

THE DETERMINATION OF INDIVIDUAL SUGARS AND ORGANIC ACIDS. In 2013 growing season, a 2 -g portion of the frozen fruit sample was ground with $20 \mathrm{~mL}$ of ultrapure water and then centrifuged at 20,000 $g_{\mathrm{n}}$ for $15 \mathrm{~min}$ at $4{ }^{\circ} \mathrm{C}$. The supernatant was recovered and immediately filtered through a $0.45-\mathrm{mm}$ filter (SepPak; Waters, Milford, MA) to eliminate large particles. The extraction was stored at $-80{ }^{\circ} \mathrm{C}$ in a sealed tube for the high-performance liquid chromatography (1200; Agilent, Santa Clara, CA) determination of individual sugar and organic acid concentration. Sweetness value $=$ fructose $\times 1.75+$ glucose $\times 0.70+$ sorbitol $\times 0.40+$ sucrose $\times 1.00$ (Song et al., 2012). 


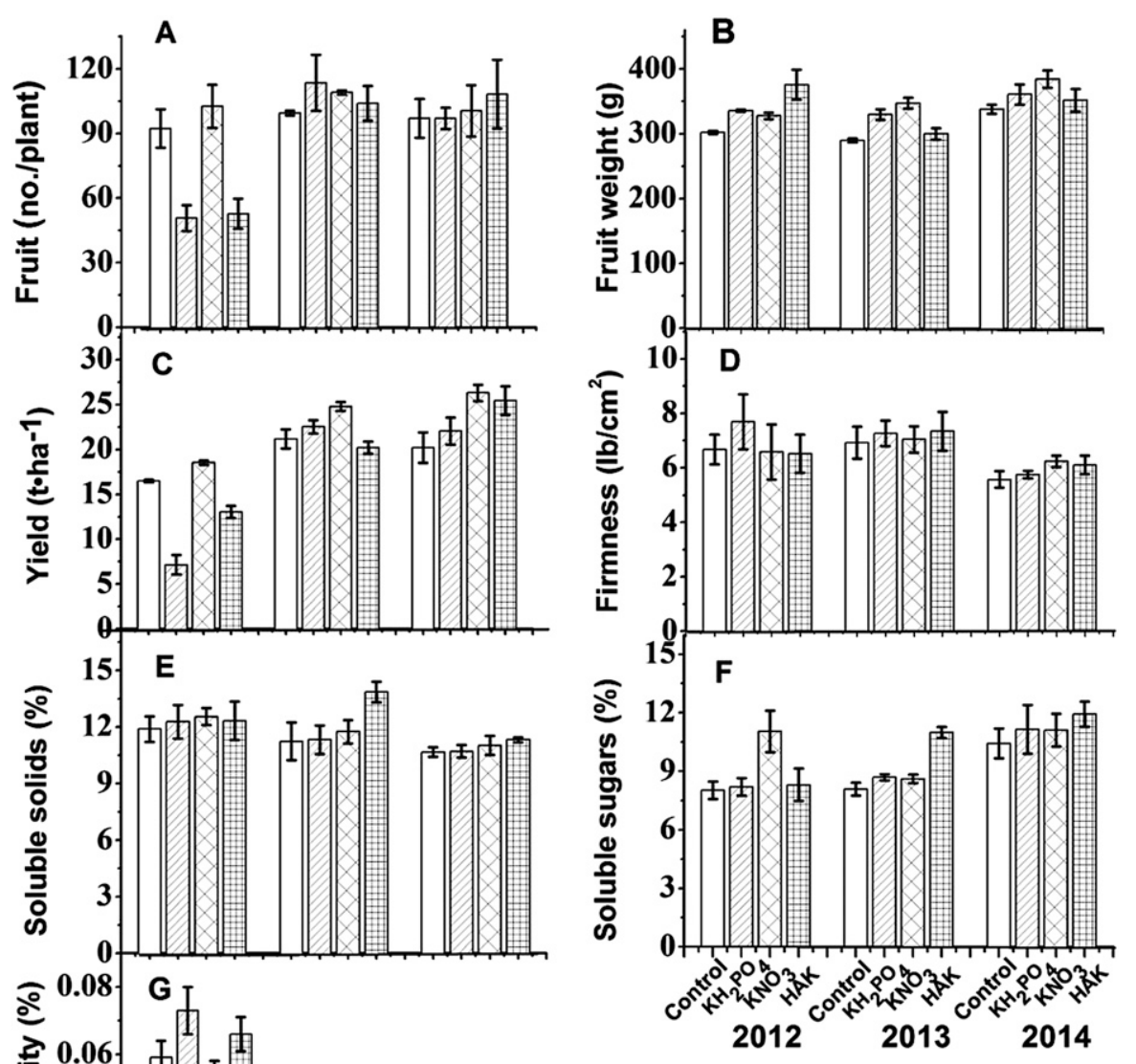

allowed to cool to room temperature, and the solution was filtered through wet filter paper and collected in a $50-\mathrm{mL}$ volumetric flask. The residue was mixed with $20 \mathrm{~mL}$ of citrate buffer ( $\mathrm{pH} 2.2)$ and the amino acid profile was determined using an automatic amino acid analyzer (Biochrom 30; Biochrom, Cambridge, UK). The 18 L-amino acid standards [i.e., glycine (Gly), alanine (Ala), serine (Ser), proline (Pro), valine (Val), threonine (Thr), cysteine (Cys), leucine (Leu), isoleucine (Ile), aspartic acid (Asp), glutamic acid (Glu), methionine (Met), histidine (His), lysine (Lys), phenylalanine (Phe), arginine (Arg), tyrosine (Tyr), and tryptophan (Trp)] were purchased from Sigma-Aldrich.

OTher calculations. The fruit number per tree was counted during the fruit expansion stage. The biomass of the fruit was calculated by single fruit weight and fruit number. According to the method of leaf-tofruit ratio (LFR) reported in apple trees by Sabbatini and Flore (2006), we corrected the LFR as 37:1, by which we can calculate the fruit biomass at the base of leaf biomass. The total $\mathrm{K}$ accumulation in leaves and fruit were calculated according to the following equations:

$$
\begin{aligned}
& \text { Leaf } \mathrm{K} \text { accumulation }\left(\mathrm{kg} \cdot \mathrm{ha}^{-1}\right) \\
& =\text { leaf biomass }\left(\mathrm{kg} \cdot \mathrm{ha}^{-1}\right) \\
& \quad \times \text { leaf } \mathrm{K} \text { concentration }(\%) \times 10^{-2}
\end{aligned}
$$

Fig. 1. Effect of different foliar potassium (K) fertilizers on yield and quality: (A) fruit number, (B) fruit weight, (C) yield, (D) firmness, (E) soluble solids, (F) soluble sugars, and (G) titratable acidity of 'Kousui' japanese pear in 2012-14 $\left(\mathrm{KH}_{2} \mathrm{PO}_{4}=\right.$ potassium phosphate monobasic, $\mathrm{KNO}_{3}=$ potassium nitrate, $\mathrm{HAK}=$ humic acid potassium). Vertical bars indicate $\mathrm{SE} ; 1 \mathrm{~g}=0.0353 \mathrm{oz}, 1 \mathrm{t} \cdot \mathrm{ha}^{-1}=$ 0.4461 ton/acre, $1 \mathrm{lb} / \mathrm{cm}^{2}=6.4516 \mathrm{psi}=44.4822 \mathrm{kPa}$.

The individual sugar concentration was determined using the following specific conditions as described by Colaric et al. (2007) with some modifications: $4.6 \times 250-\mathrm{mm}, 5-\mu \mathrm{m}$ column (CapCell Pak NH2; Shiseido, Tokyo, Japan), constant temperature of $50{ }^{\circ} \mathrm{C}$, and mobile phase of acetonitrile-water $(80 / 20 ; \mathrm{v} / \mathrm{v})$. An evaporative light scattering detector (Alltech 3300 ELSD; Grace, Deerfield, IL) was used with a flow rate of $1.0 \mathrm{~mL} \cdot \mathrm{min}^{-1}$, drift tube temperature of $80{ }^{\circ} \mathrm{C}$, and nitrogen flow rate of $2.0 \mathrm{~mL} \cdot \mathrm{min}^{-1}$. The individual organic acid concentration was determined using the following specific conditions as described by $\mathrm{Xu}$ et al. (2012) with slight revisions as follows: $4.6 \times 250-\mathrm{mm}, 5-\mu \mathrm{m}$ column (C18, Waters) with $1 \mathrm{~mL} \cdot \mathrm{L}^{-1}$ phosphoric acid aqueous solution, flow rate of $0.8 \mathrm{~mL} \cdot \mathrm{min}^{-1}$, column temperature of $45{ }^{\circ} \mathrm{C}$, injection volume of $20 \mu \mathrm{L}$, and detection at $210 \mathrm{~nm}$ using an ultraviolet spectrophotometer.

The Determination OF AMINO ACIDs. According to Coimbra et al. (2011), each fresh fruit sample $(2.5 \mathrm{~g})$ was placed in a coated polytetrafluoroethylene test tube with a screw cap. To each sample, $10 \mathrm{~mL}$ of $6 \mathrm{M}$ $\mathrm{HCl}$ was added. The tube was filled with nitrogen over a 15 -min period and sealed. The hydrolysis reaction was performed for $24 \mathrm{~h}$ at $110^{\circ} \mathrm{C}$ using a heating block. The tube was

$$
\begin{aligned}
& \text { Fruit } \mathrm{K} \text { accumulation }\left(\mathrm{kg} \cdot \mathrm{ha}^{-1}\right) \\
& =\text { fruit biomass }\left(\mathrm{kg} \cdot \mathrm{ha}^{-1}\right) \\
& \quad \times \text { fruit } \mathrm{K} \text { concentration }(\%) \times 10^{-2}
\end{aligned}
$$

Data AnAlysis. Data were analyzed by analysis of variance using SAS (version 9.3; SAS Institute, Cary, NC). Means were compared for treatment effects using a Fisher's protected least significant difference at $P<0.05$.

\section{Results}

EFFECTS ON FRUIT YIELD AND QUALITY PARAMETERS IN 2012-14. On the whole, in the three growing seasons, foliar $\mathrm{K}$ fertilization resulted in an increasing trend in fruit weight (Fig. 1B). In the first growing season (2012), there were large differences in the number of fruit that the trees bore. The number of fruit in the $\mathrm{KH}_{2} \mathrm{PO}_{4}$ and HAK treatments was almost half of that in the $\mathrm{KNO}_{3}$ treatment (Fig. 1A), which led to 


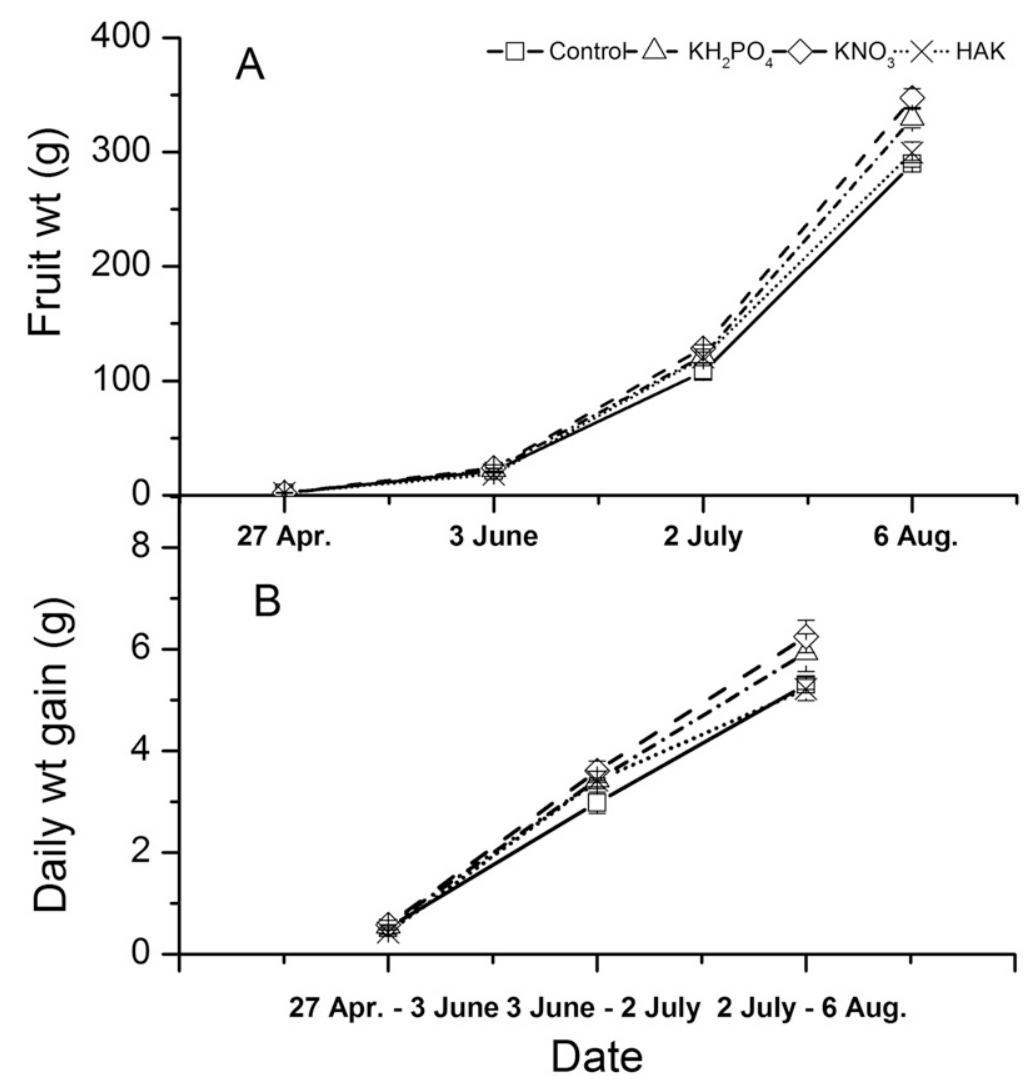

Fig. 2. Effect of different foliar potassium (K) fertilizers on 'Kousui' japanese pear (A) fruit weight and (B) daily weight gain in $2013\left(\mathrm{KH}_{2} \mathrm{PO}_{4}=\right.$ potassium phosphate monobasic, $\mathrm{KNO}_{3}$ = potassium nitrate, $\mathrm{HAK}=$ humic acid potassium). Daily weight gain was calculated as the difference of weight between the two sampling dates divided by the days. Vertical bars indicate SE; $1 \mathrm{~g}=0.0353 \mathrm{oz}$.

great difference in yield (Fig. IC). It was suggested that the fruit number was very essential and during the subsequent two seasons, the fruit number was hand controlled around 100. In 2013 and 2014, three foliar K sources led to an increasing trend in fruit yield, firmness (Fig. 1D), SSC (Fig. 1F), and TA (Fig. 1G). The application of $\mathrm{KNO}_{3}$ in these two seasons led to an average $16 \%$ higher yield than the control. The yield of HAK treatment was significantly lower than that of the $\mathrm{KNO}_{3}$ treatment in 2013, whereas HAK resulted in $26 \%$ higher yield than the control in 2014. No significant differences were found in the yield of $\mathrm{KH}_{2} \mathrm{PO}_{4}$ treatment either in 2013 or 2014. From 2013 to 2014 , comparing with the control, SSC (Fig. 1E), total soluble sugar, and TA were increased by an average of $15 \%, 25 \%$, and $21 \%$, respectively, in HAK treatment.

FRUIT WEIGHT AND DAILY WEIGHT GAIN. As shown in Fig. 2A and 2B, the single fruit weight and daily weight gains of fruit in the control gradually increased with fruit growth. In maturity, the fruit weight of $\mathrm{KNO}_{3}$ treatment was significantly higher than that of the control and HAK. The daily weight gain from the expansion phase II to maturity (i.e., 2 July to 6 Aug.) was on average 10 times higher than that from the young fruit stage to the expansion phase I (i.e., 27 Apr. to 3 June), and was on average 0.7 times higher than that from expansion phase I to expansion phase II (3 June to 2 July). Upon foliar application of $\mathrm{KH}_{2} \mathrm{PO}_{4}$ and $\mathrm{KNO}_{3}$, the single fruit weights were $16 \%$ and $17 \%$ higher than the control at the expansion phase II (2 July) and maturity (6 Aug.), respectively. During expansion phase II (2 July) and maturity (6 Aug.), daily weight gains were $21 \%$ and $18 \%$ higher in plants treated with $\mathrm{KNO}_{3}$ than in the control.

DYNAMIC CHANGES IN K CONCENTRATION AND ACCUMULATION IN LEAVES AND FRUIT. The leaf $\mathrm{K}$ concentration in the control plants was among the lowest during all developmental stages (Fig. 3A). From young fruit to maturity, $\mathrm{K}$ concentration was significantly increased by foliar $\mathrm{KNO}_{3}$ and HAK. From fruit harvest to leaf fall, leaf $\mathrm{K}$ concentration and accumulation was increased first and then decreased (Fig. 3A and 3C). During fruit development, the fruit $\mathrm{K}$ concentration decreased from $2.5 \%$ to $0.15 \%$. There was no significant difference in the accumulation of $\mathrm{K}$ in leaves between plants treated with $\mathrm{KNO}_{3}$ and $\mathrm{HAK}$ at maturity (i.e., 6 Aug.; Fig. 3C). Furthermore, K accumulation was $38 \%$ and $14 \%$ higher in the leaves of samples sprayed with $\mathrm{HAK}\left(\mathrm{KNO}_{3}\right)$ and $\mathrm{KH}_{2} \mathrm{PO}_{4}$ than in those of the control, respectively (Fig. $3 \mathrm{C})$. However, there was no significant difference between the fruit $\mathrm{K}$ accumulation in $\mathrm{KNO}_{3}$ and $\mathrm{KH}_{2} \mathrm{PO}_{4}$ (Fig. 3D), which was an average of $22 \%$ and $43 \%$ higher than that in HAK and the control, respectively. From expansion stage II to maturity, Kaccumulation in leaves and fruit accounted for $61 \%$ and $91 \%$ of the total $\mathrm{K}$ accumulation. Therefore, it could be concluded that expansion stage II is the critical stage of 'Kousui' japanese pear tree for $\mathrm{K}$ demand.

Fruit INDIVIDUAL SUGAR CONCENTRATION AND SWEETNESS. FOliar application of $\mathrm{K}$ fertilizers resulted in a significant increase in the concentration of fructose, which was on average $22 \%$ higher than in the control (Fig. 4A). The sorbitol concentration of the $\mathrm{KH}_{2} \mathrm{PO}_{4}$ and $\mathrm{HAK}$ treatment groups were an average of $35 \%$ higher than in the control (Fig. $4 \mathrm{~B})$. The glucose concentration in the fruit of $\mathrm{KH}_{2} \mathrm{PO}_{4}$ treatment was the highest of all, followed by that of the $\mathrm{KNO}_{3}$ treatment (Fig. 4C). HAK and $\mathrm{KNO}_{3}$ treatment resulted in a significant increase in sucrose concentration compared with the control and $\mathrm{KH}_{2} \mathrm{PO}_{4}$ treatment (Fig. 4D). Total sugar and sweetness of fruit of each treatment were consistent with the fructose concentration, which were both $28 \%$ higher than the control (Fig. 4E and 4F).

FRUIT INDIVIDUAL ORGANIC ACID CONCENTRATION. Total acid concentration in fruit was significantly increased by the foliar application of $\mathrm{K}$ fertilizers (Fig. 5G). $\mathrm{KH}_{2} \mathrm{PO}_{4}$ treatment led to a $105 \%, 61 \%, 112 \%$, and $59 \%$ increase in malate, succinic acid, shikimic acid, and citric acid, respectively (Fig. 5A-C and 5F). However, the concentration of malate and shikimic acid in HAK treatment was $43 \%$ and $142 \%$ higher than that of the 


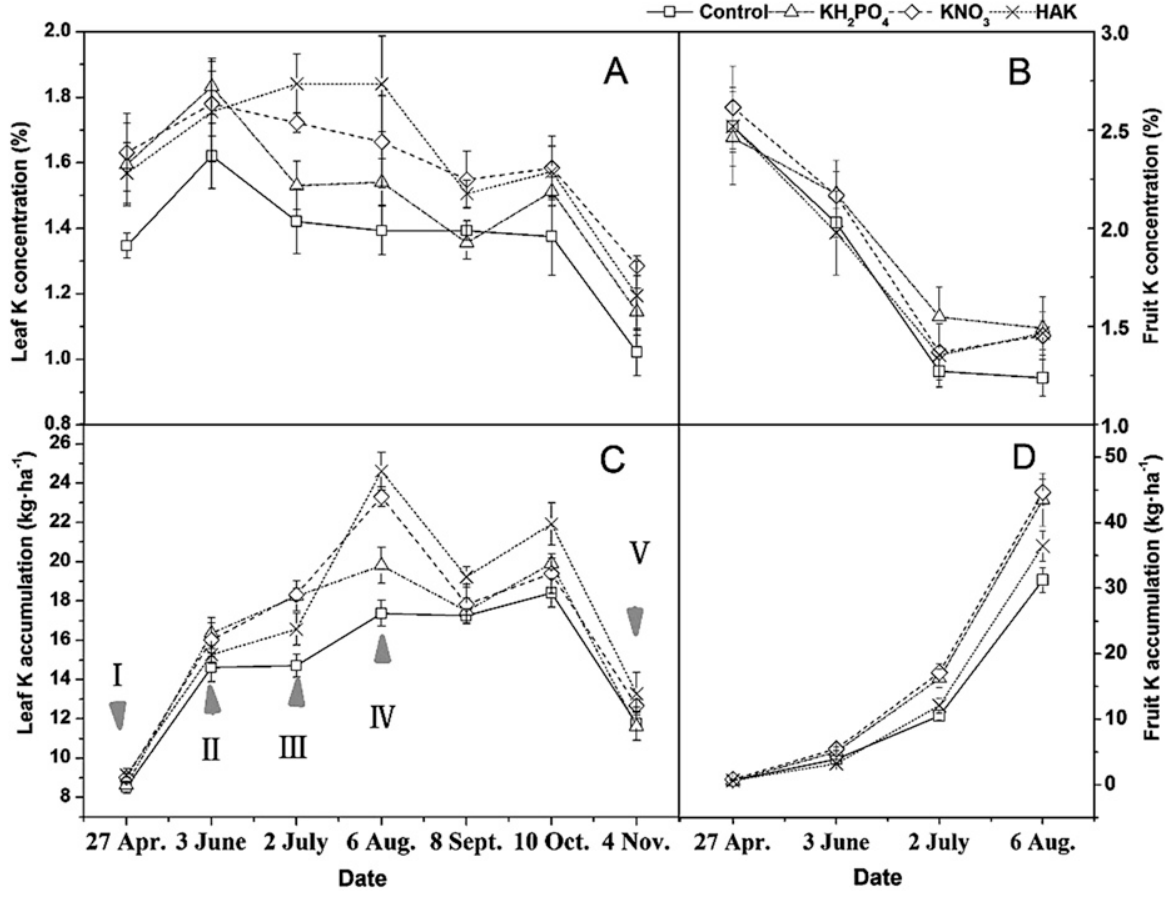

Fig. 3. Effect of different foliar potassium (K) fertilizers on (A) leaf $\mathrm{K}$ concentration and $(C)$ leaf $K$ accumulation, and (B) fruit $K$ concentration and (D) leaf $\mathrm{K}$ accumulation of 'Kousui' japanese pear in 2013. In Fig. 3C, shaded arrows indicate sampling time, I-III: Spraying time; IV: Fruit harvest; V: Leaf abscission $\left(\mathrm{KH}_{2} \mathrm{PO}_{4}=\right.$ potassium phosphate monobasic, $\mathrm{KNO}_{3}=$ potassium nitrate, $\mathrm{HAK}=$ humic acid potassium). Vertical bars indicate $\mathrm{SE} ; 1 \mathrm{~kg} \cdot \mathrm{ha}^{-1}=0.8922 \mathrm{lb} /$ acre.
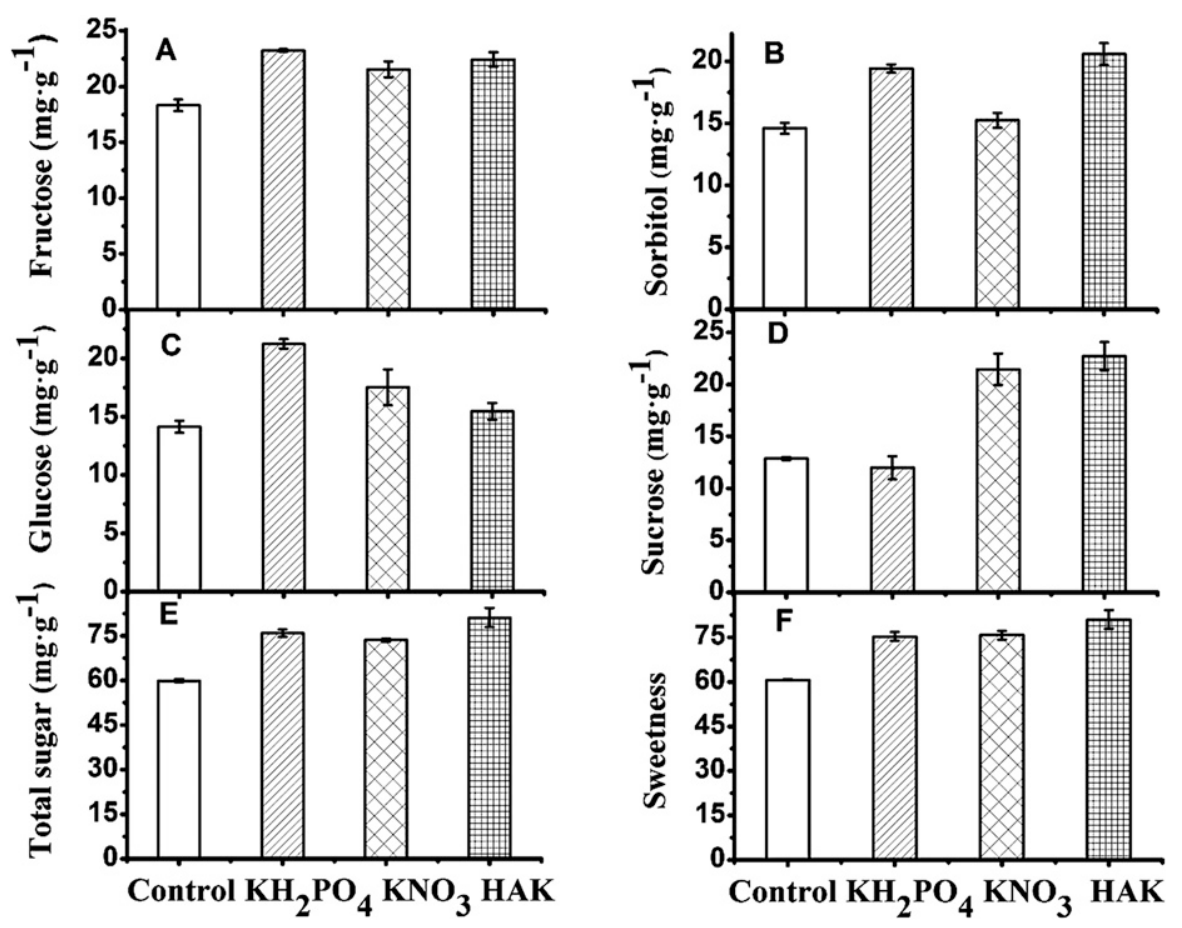

Fig. 4. Effect of different foliar potassium (K) fertilizers on fruit sugar concentration: (A) fructose, (B) sorbitol, (C) glucose, (D) sucrose, (E) total sugar, and $(\mathrm{F})$ sweetness of 'Kousui' japanese pear in $2013\left(\mathrm{KH}_{2} \mathrm{PO}_{4}=\right.$ potassium phosphate monobasic, $\mathrm{KNO}_{3}=$ potassium nitrate, $\mathrm{HAK}=$ humic acid potassium). Total sugar $=$ fructose + sorbitol + glucose + sucrose; sweetness value $=$ fructose $\times$ $1.75+$ glucose $\times 0.70+$ sorbitol $\times 0.40+$ sucrose $\times 1.00$. Vertical bars indicate $S E ;$ $1 \mathrm{mg} \cdot \mathrm{g}^{-1}=1000 \mathrm{ppm}$. control. Compared with the control, $\mathrm{KNO}_{3}$ treatment had no significant difference of acid concentration except for malate. Concerning oxaloacetic acid and tartaric acid of the fruit (Fig. 5D and 5E), it was observed that there were no significant differences with different treatments.

Fruit INDIVIDUAL AMINO ACID CONCENTRATION. Except for the essential amino acid Trp, the concentration of the 17 amino acids was examined in the 'Kousui' japanese pear fruit (Table 1). A significant increase was found in the concentration of some nonessential amino acids, such as Asp, Ser, Glu, and Gly. Asp is in the highest level in nonessential amino acid group, accounting for $67 \%$ to $72 \%$ of the total nonessential amino acids, and $49 \%$ to $55 \%$ of total amino acids. Foliar application of $\mathrm{KNO}_{3}$ and HAK treatments led to $12 \%$ and $22 \%$ higher Asp, respectively, than in the control, whereas $\mathrm{KNO}_{3}$ treatment resulted in $25 \%, 49 \%$, and $23 \%$ higher Ser, Glu, and Gly than in the control and in the $\mathrm{KH}_{2} \mathrm{PO}_{4}$ treatment. However, of all the seven essential amino acids presented in 'Kousui' japanese pear fruit, Val and Thr were the most abundant amino acids, representing $22 \%$ and $20 \%$ of the total essential amino acid concentration, respectively. Hardly any effect was observed on the essential amino acid concentration by the foliar application of the three $\mathrm{K}$ fertilizers, except for the concentration of Thr in HAK treatment, which was $13 \%$ higher than that in the control. With regard to the total amino acid concentration, foliar application of $\mathrm{KNO}_{3}$ and $\mathrm{HAK}$ led to $17 \%$ and $15 \%$ higher amounts than the control, respectively.

\section{Discussion}

EFFECTS ON FRUIT GROWTH RATE, YIELD, AND K ACCUMULATION. In the present study, two successive growing seasons (2013 and 2014) of foliar application of $\mathrm{KNO}_{3}$ fertilizer led to a significant increase in fruit weight and daily fruit weight gain, whereas spraying with $\mathrm{KH}_{2} \mathrm{PO}_{4}$ had no significant effect. Spraying with $\mathrm{KNO}_{3}$ was previously reported to increase fruit size in 'Patharnakh' japanese pear (Gill et al., 2012), and the increase was greatest at a dose of $1.5 \% \mathrm{KNO}_{3}$. A study of plum trees [Prunus salicina (Southwick et al., 1996)] revealed that there was a correlation among the dry weight, size of fruit, 

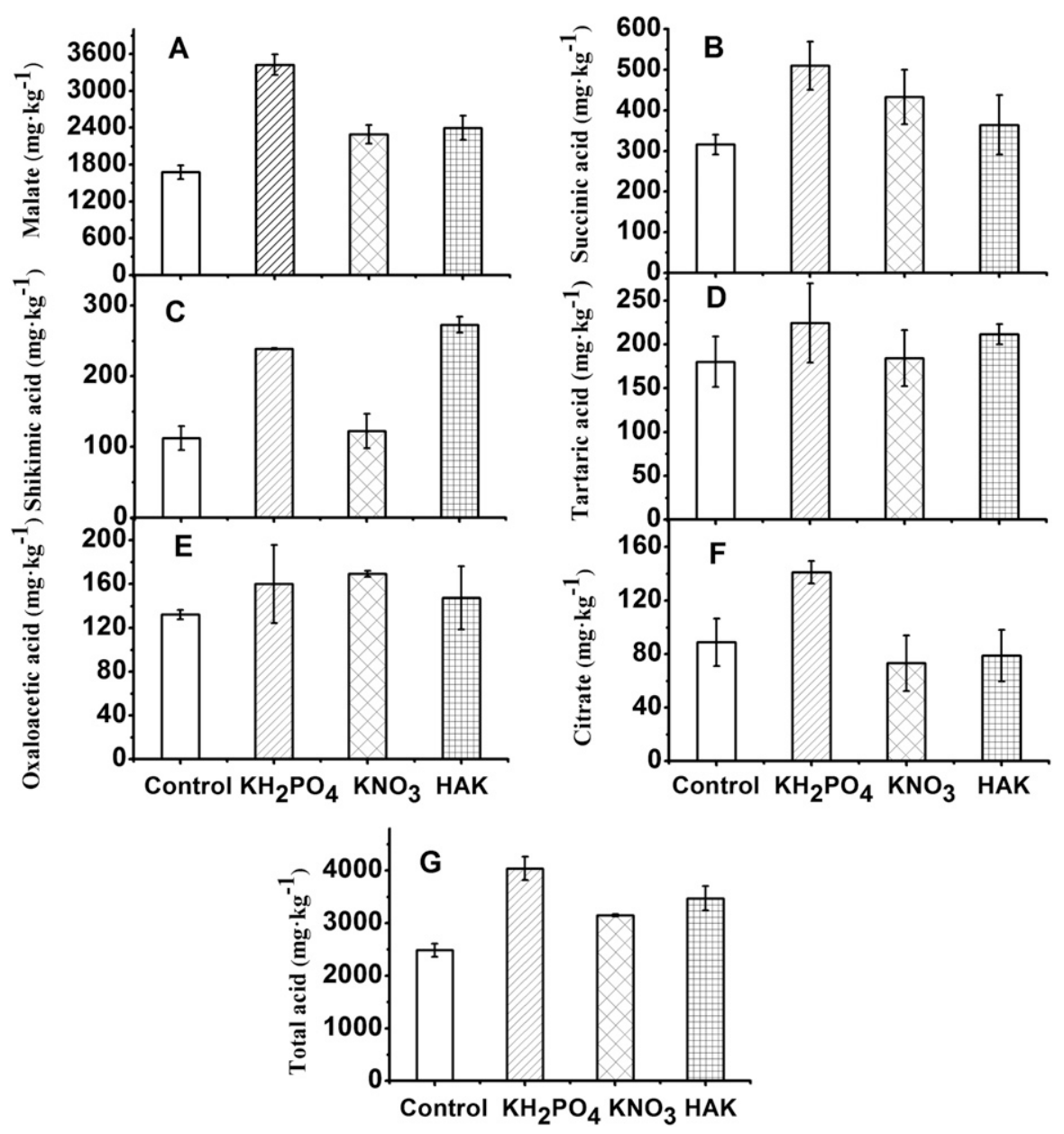

Fig. 5. Effect of different foliar potassium (K) fertilizers on fruit acid concentration: (A) malate, (B) succinic acid, (C) shikimic acid, (D) tartaric acid, (E) oxaloacetic acid, $(F)$ citric acid, and $(G)$ total acid of 'Kousui' japanese pear in $2013\left(\mathrm{KH}_{2} \mathrm{PO}_{4}=\right.$ potassium phosphate monobasic, $\mathrm{KNO}_{3}=$ potassium nitrate, HAK $=$ humic acid potassium $).$ Total acid $=$ malate + succinic acid + shikimic acid + tartaric acid + oxaloacetic acid + citric acid. Vertical bars indicate SE; $1 \mathrm{mg} \cdot \mathrm{kg}^{-1}=1 \mathrm{ppm}$.

and the $\mathrm{K}$ concentration of leaves, showing that a moderate fruit size required a higher $\mathrm{K}$ concentration in the leaves. This was consistent with our results of $\mathrm{KNO}_{3}$ treatment, which could efficiently increase K levels both in the leaves and the fruit (Fig. 3). From the expansion phase I to leaf abscission (i.e., 3 June to 4 Nov.), the K concentration of leaves significantly decreased in the control, but this reduction could be alleviated by foliar application of $\mathrm{K}$ fertilizers. Sufficient $\mathrm{K}$ level in the leaves during the expansion phase is critical for fruit development, since a large amount of photosynthetic production is required for fruit enlargement. It has been shown that leaf $\mathrm{K}$ concentration had a nutrient backflowing process after fruit harvest, which might be related to the nutrient reflux of $\mathrm{K}$ (Fig. 3A). Compared with the control, the foliar application of $\mathrm{K}$ fertilizers significantly increased $\mathrm{K}$ backflow efficiency in leaves. Proe et al. (2000) found that increasing the nutrient supply increased the amount of $\mathrm{K}$ remobilized from $49 \%$ to $57 \%$ of initial concentration in scots pine. This might reflect the contrasting physiological roles of $\mathrm{N}$ and $\mathrm{K}$ and the greater proportion of $\mathrm{K}$ available for remobilization. In the study, the leaf $\mathrm{K}$ concentration in the control was $22 \%$ lower than those treated with $\mathrm{KNO}_{3}$ at the expansion phase I, which was suggested that there might be some risks of $\mathrm{K}$ insufficiency if no additional $\mathrm{K}$ fertilizer was supplied at the start of expansion phase I.
EFFECT ON FRUIT SUGAR AND ORGANIC ACID CONCENTRATION. K has been widely known as a "quality element" in fruit production, which can significantly improve fruit quality (Zörb et al., 2014). Sugar and acids concentration are regarded as two of the most important parameters of fruit quality. It was shown that in 'Kousui' japanese pear fruit, fructose and malate were dominant in the soluble sugars and organic acids, respectively (Figs. 4 and 5), consistent with the report by Chen et al. (2007) in the fruit of 'Niitaka' japanese pear. In the present study, fructose concentration was found to account for $28 \%$ to $31 \%$ of the total sugars (Fig. 4A and 4E), and malate $67 \%$ to $85 \%$ of the total organic acids concentration (Fig. 5A and $5 \mathrm{G}$ ). It was found that foliar spraying with $\mathrm{K}$ fertilizers could increase fruit firmness and total soluble sugar, in agreement with a previous study (Lester et al., 2010b). HAK treatment strongly increased fruit firmness, SSC, and total soluble sugar in 2013 and 2014 (Fig. 1), which was suggested as an efficient measurement to improve fruit quality. The application of $\mathrm{K}$ fertilizers all increased the total concentration of organic acids (Fig. 5G), which agreed with Mukadam and Haldankar (2012) in karonda (Carissa carandas). It was clearly shown that different accompanied ions might result in a specific difference in the metabolism of various kinds of sugars and organic acids in the fruit (Figs. 4 and 5).

EFFECTS ON FRUIT AMINO ACID CONCENTRATION. In the present study, foliar application of $\mathrm{K}$ fertilizers had no effect on the total concentration of fruit essential amino acids. However, the concentration of Asp, Ser, and Glu, which belong to the nonessential amino acids, increased to various degrees (Table 1). Asp had an important role in fruit flavor (Ardö, 2006), and was the most abundant amino acid in 'Kousui' japanese pear, accounting for a maximum of $75 \%$ of the total amino acid concentration. Asp was significantly increased upon spraying with $\mathrm{KNO}_{3}$ and HAK (Table 1). During $\mathrm{NO}_{3}{ }^{-}$assimilation, $\mathrm{NO}_{3}{ }^{-}$is first assimilated as ammonia in leaves and is then converted into Glu by the glutamine synthetase and glutamate synthase pathways (Rufty et al., 1981). When ammonia is assimilated into glutamate and glutamine, it can be converted 
Table 1. Effect of different foliar potassium (K) fertilizers on 'Kousui' japanese pear fruit nonessential amino acids (NEAA) and essential amino acids (EAA).

\begin{tabular}{|c|c|c|c|c|c|c|c|c|c|}
\hline \multirow[b]{2}{*}{$\underline{\text { Amino } \operatorname{acid}^{\mathrm{z}}}$} & \multicolumn{4}{|c|}{ Fruit NEAA $(\mathrm{mg} / 100 \mathrm{~g} \mathrm{FW})^{\mathrm{y}}$} & \multirow[b]{2}{*}{ Amino acid } & \multicolumn{4}{|c|}{ Fruit EAA (mg/100 g FW) } \\
\hline & Control & $\mathrm{KH}_{2} \mathrm{PO}_{4}$ & $\mathrm{KNO}_{3}$ & HAK & & Control & $\mathrm{KH}_{2} \mathrm{PO}_{4}$ & $\mathrm{KNO}_{3}$ & HAK \\
\hline Asp & $98.41 c^{x}$ & $97.96 \mathrm{c}$ & $110.63 \mathrm{~b}$ & $120.40 \mathrm{a}$ & Val & $10.53 \mathrm{a}$ & $11.57 \mathrm{a}$ & $10.97 \mathrm{a}$ & $11.58 \mathrm{a}$ \\
\hline Ala & $8.68 \mathrm{a}$ & $9.51 \mathrm{a}$ & $9.50 \mathrm{a}$ & $9.09 \mathrm{a}$ & Leu & $8.56 \mathrm{a}$ & $9.20 \mathrm{a}$ & $8.43 \mathrm{a}$ & 8.93 a \\
\hline Ser & $6.76 \mathrm{~b}$ & $6.75 \mathrm{~b}$ & $8.42 \mathrm{a}$ & $7.33 \mathrm{ab}$ & Ile & $7.17 \mathrm{a}$ & $7.04 \mathrm{a}$ & $6.70 \mathrm{a}$ & $7.15 \mathrm{a}$ \\
\hline Arg & 6.75 & $6.72 \mathrm{a}$ & $7.28 \mathrm{a}$ & $7.08 \mathrm{a}$ & Lys & $6.09 \mathrm{a}$ & $7.07 \mathrm{a}$ & $7.16 \mathrm{a}$ & $6.98 \mathrm{a}$ \\
\hline Cys & $1.04 \mathrm{a}$ & $1.20 \mathrm{a}$ & $1.06 \mathrm{a}$ & $1.43 \mathrm{a}$ & Total EAA & $49.35 \mathrm{a}$ & $51.04 \mathrm{a}$ & $50.65 \mathrm{a}$ & $53.60 \mathrm{a}$ \\
\hline Tyr & $1.99 \mathrm{a}$ & $2.22 \mathrm{a}$ & $1.94 \mathrm{a}$ & $2.10 \mathrm{a}$ & & & & & \\
\hline His & $2.83 \mathrm{a}$ & $2.81 \mathrm{a}$ & $3.17 \mathrm{a}$ & $3.07 \mathrm{a}$ & Total amino acids & $192.51 \mathrm{c}$ & $198.21 \mathrm{bc}$ & $215.89 \mathrm{ab}$ & $224.88 \mathrm{a}$ \\
\hline Total NEAA & $143.17 \mathrm{~b}$ & $148.42 \mathrm{~b}$ & $162.80 \mathrm{a}$ & $171.28 \mathrm{a}$ & $(\mathrm{NEAA}+\mathrm{EAA})$ & & & & \\
\hline
\end{tabular}

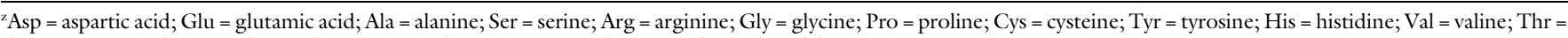
threonine; Leu = leucine; Ile = isoleucine; Lys = lysine; Met = methionine; Phe = phenylalanine.

${ }^{\prime} \mathrm{KH}_{2} \mathrm{PO}_{4}=$ potassium phosphate monobasic; $\mathrm{KNO}_{3}=$ potassium nitrate; $\mathrm{HAK}=$ humic acid potassium; $1 \mathrm{mg} / 100 \mathrm{~g}=10 \mathrm{ppm}$.

${ }^{x}$ Means followed by the same letter within the treatment were not significantly different by Fisher's least significant difference test at $P<0.05$ ( $\mathrm{n}=6$ ).

into other amino acids by transamination, and this process is promoted by $\mathrm{K}$ (Mengel et al., 1981), since K functions as a cofactor that promotes the assimilation of amino acids. It was discovered by Armengaud et al. (2009) that regulation of enzymes at the level of transcripts and proteins was likely to play an important role in Arabidopsis (Arabidopsis thaliana) adaptation to $\mathrm{K}$ deficiency by decreasing negative metabolic charge, such as Glu, Asp, nitrate, and malate, whereas $\mathrm{K}$ supply could increase negative charge. Lin et al. (2004) reported that the taste, aroma, and Glu and Asp concentration of muskmelon could be improved when $\mathrm{K}$ was present at a level of $240 \mathrm{mg} \cdot \mathrm{L}^{-1}$ in the nutrient solution, which was consistent with our present study.

\section{Conclusion}

Comparatively speaking, foliar application of $\mathrm{KNO}_{3}$ could significantly increase the $\mathrm{K}$ accumulation, the fructose and sucrose concentration, and some amino acids in the fruit, such as Asp, Ser, Glu, and Gly. Further, compared with $\mathrm{KNO}_{3}, \mathrm{HAK}$ was more helpful to improve the fruit quality by increasing fruit firmness, the total SSC, and sweetness. Farmers should adopt different strategies according to the aim of whether to increase the fruit yield or improve the fruit quality.

\section{Literature cited}

Adams, E. and R. Shin. 2014. Transport, signaling, and homeostasis of potassium and sodium in plants. J. Integr. Plant Biol. 56:231-249.
Alexander, L. and C.A. Edwards. 2003. A microtiter modification of the anthronesulfuric acid colorimetric assay for glucosebased carbohydrates. Anal. Biochem. 315: $143-145$.

Allen, S.E., H.M. Grimshaw, J.A. Parkinson, and C.L. Quarmby. 1974. Chemical analysis of ecological materials. Blackwell Scientific Publications, Oxford/London, UK.

Ashraf, M.Y., G. Attiya, A. Muhammad, F. Hussain, and G. Ebert. 2010. Improvement in yield and quality of kinnow (Citrus deliciosa x Citrus nobilis) by potassium fertilization. J. Plant Nutr. 33: 1625-1637.

Ardö, Y. 2006. Flavour formation by amino acid catabolism. Biotechnol. Adv. 24:238-242.

Armengaud, P., R. Sulpice, A.J. Miller, M. Stitt, A. Amtmann, and Y. Gibon. 2009. Multilevel analysis of primary metabolism provides new insights into the role of potassium nutrition for glycolysis and nitrogen assimilation in Arabidopsis roots. Plant Physiol. 150:772-785.

Baraldi, R., F.F.F. Malavasi, S. Predieri, and M. Castagneto. 1991. Effect of potassium humate on apple cv. 'Golden Delicious' cultured in vitro. Plant Cell Tiss. Organ Cult. 24:187-191.

Boyer, P.D., H.A. Lardy, and P.H. Phillips. 1943. Further studies on the role of potassium and other ions in the phosphorylation of the adenylic system. J. Biol. Chem. 149:529-541.

Calvert, D.V. and R.C. Smith. 1972. Correction of potassium deficiency of citrus with potassium nitrate sprays. J. Agr. Food Chem. 20:659-661.

Chen, J.L., Z.F. Wang, J.H. Wu, Q Wang, and X.S. Hu. 2007. Chemical compositional characterization of eight pear cultivars grown in China. Food Chem. 104:268-275.

Coimbra, M.A., C. Nunes, P.R. Cunha, and R. Guiné. 2011. Amino acid profile and Maillard compounds of sun-dried pears. Relation with the reddish brown colour of the dried fruits. Eur. Food Res. Technol. 233:637-646.

Colaric, M., F. Stampar, and M. Hudina. 2007. Content levels of various fruit metabolites in the 'Conference' pear response to branch bending. Scientia Hort. 113:261-266.

Dong, S., D. Neilsen, G.H. Neilsen, and L.H. Fuchigami. 2005. Foliar N application reduces soil $\mathrm{NO}_{3}^{-}-\mathrm{N}$ leaching loss in apple orchards. Plant Soil 268: 357-366.

Gill, P., M.Y. Ganaie, W.S. Dhillon, and N.P. Singh. 2012. Effect of foliar sprays of potassium on fruit size and quality of 'Patharnakh' pear. Indian J. Hort. 69: 512-516.

Gill, P., S.N. Singh, and A.S. Dhatt. 2005. Effect of foliar application of $\mathrm{K}$ and $\mathrm{N}$ fertilizers on fruit quality of Kinnow mandarin. Indian J. Hort. 62:282-284.

Horta, M.D.C. and J. Torrent. 2007. The Olsen $\mathrm{P}$ method as an agronomic and environmental test for predicting phosphate release from acid soils. Nutr. Cycl. Agroecosyst. 77:283-292.

Hudina, M. and F. Stampar. 2002. Effect of phosphorus and potassium foliar fertilization on fruit quality of pears. Acta Hort. 594:487-493.

Jifon, J.L. and G.E. Lester. 2009. Foliar potassium fertilization improves fruit quality of field-grown muskmelon on calcareous soils in south Texas. J. Sci. Food Agr. 89:2452-2460. 
Karley, A.J. and P.J. White. 2009. Moving cationic minerals to edible tissues: Potassium, magnesium, calcium. Curr. Opin. Plant Biol. 12:291-298.

Lebaudy, A., A.A. Véry, and H. Sentenac. 2007. $\mathrm{K}^{+}$channel activity in plants: Genes, regulations and functions. FEBS Lett. 581:2357-2366.

Lester, G.E., J.L. Jifon, and D.J. Makus. 2006. Supplemental foliar potassium applications with or without a surfactant can enhance netted muskmelon quality. HortScience 41:741-744.

Lester, G.E., J.L. Jifon, and D.J. Makus. 2010a. Impact of potassium nutrition on food quality of fruits and vegetables: A condensed and concise review of the literature. Better Crops Plant Food 94: 18-21.

Lester, G.E., J.L. Jifon, and D.J. Makus. $2010 \mathrm{~b}$. Impact of potassium nutrition on postharvest fruit quality: Melon ( $\mathrm{Cucu}$ mis melo L) case study. Plant Soil 335: 117-131.

Lin, D., D.F. Huang, and S.P. Wang. 2004. Effects of potassium levels on fruit quality of muskmelon in soilless medium culture. Scientia Hort. 102:53-60.

Lu, R.K. 1999. Soil chemical analysis methods in agriculture. China Agr. Sci. Tech. Press, Beijing, China. (in Chinese).

Mengel, K., M. Secer, and K. Koch. 1981. Potassium effect on protein formation and amino acid turnover in developing wheat grain. Agron. J. 73:74-78.

Mpelasoka, B.S., D.P. Schachtman, M.T. Treeby, and M.R. Thomas. 2003. A review of potassium nutrition in grapevines with special emphasis on berry accumulation. Austral. J. Grape Wine Res. 9: 154-168

Mukadam, S.J. and P.M. Haldankar. 2012. Effect of paclobutrazol and post flowering foliar sprays of nutrients for accelerating harvesting of karonda ( $\mathrm{Car}$ issa carandas Linn.). J. Plant Studies 2: 145-147.

Niu, J.F., W.F. Zhang, S.H. Ru, X.P. Chen, K. Xiao, X.Y. Zhang, M. Assaraf, P. Imas, H. Magen, and F.S. Zhang. 2013. Effects of potassium fertilization on winter wheat under different production practices in the North China Plain. Field Crops Res. 140:69-76.

Niu, Z.M., X.F. Xu, Y. Wang, T.Z. Li, J. Kong, and Z.H. Han. 2008. Effects of leaf-applied potassium, gibberellin and source-sink ratio on potassium absorption and distribution in grape fruits. Scientia Hort. 115:164-167.

Proe, M.F., A.J. Midwood, and J. Craig. 2000. Use of stable isotopes to quantify nitrogen, potassium and magnesium dynamics in young scots pine (Pinus sylvestris). New Phytol. 146:461-470.

Rebolledo-Martínez, A., A. Lid-delÁngel-Pérez, and J. Rey-Moreno. 2008. Effects of paclobutrazol and $\mathrm{KNO}_{3}$ over flowering and fruit quality in two cultivars of mango Manila. Interciencia 33: 518-522.

Reuveni, M., M. Harpaz, and R. Reuveni. 1998a. Integrated control of powdery mildew on apple trees by foliar sprays of mono-potassium phosphate fertilizer and sterol inhibiting fungicides and the strobilurin Kresoxim-methyl. Eur. J. Plant Pathol. 104:853-860.

Reuveni, R., G. Dor, and M. Reuveni. 1998b. Local and systemic control of powdery mildew (Leveillula taurica) on pepper plants by foliar spray of monopotassium phosphate. Crop Prot. 17: 703-709.

Römheld, V. and E.A. Kirkby. 2010. Research on potassium in agriculture: Needs and prospects. Plant Soil 335:155-180.

Rufty, T.W., W.A. Jackson, and C.D. Raper. 1981. Nitrate reduction in roots as affected by the presence of potassium and by flux of nitrate through the roots. Plant Physiol. 68:605-609.

Sabbatini, P. and J. Flore. 2006. Effect of varying crop load on leaf photosynthesis and carbon isotope discrimination of 'Imperial Gala' apple tree. HortScience 41:1010. (Abstr.).

Sánchez, C. 2015. Effect of chitosan coating on quality and nutritional value of fresh-cut 'Rocha' pear. Emirates J. Food Agr. 27:206-214.

Shahryari, R., A. Gadimov, E. Gurbanov, and M. Valizade. 2009. Application of potassium humate in wheat for organic agriculture in Iran. Asian J. Food AgroInd. 2:164-168.
Shin, R. 2014. Strategies for improving potassium use efficiency in plants. Mol. Cells 37:575-584.

Sing, J.L. and R.J. McNeil. 1992. The effectiveness of foliar potassium nitrate sprays on the 'Hass' avocado (Persea americana Mill.). In: C.J. Lovatt (ed.). World Avocado Congress II, Proceedings: "the shape of things to come." $1: 337-342$.

Song, X.H., K. Xie, H.B. Zhao, Y.L. Li, C.X. Dong, Y.C. Xu, and Q.R. Shen. 2012. Effects of different organic fertilizers on tree growth, yield, fruit quality, and soil microorganisms in a pear orchard. Eur. J. Hort. Sci. 77:204-210.

Southwick, S.M., W. Olson, J. Yeager, and K.G. Weis. 1996. Optimum timing of potassium nitrate spray applications to 'French' prune trees. J. Amer. Soc. Hort. Sci. 121:326-333.

Walker, D.J., R.A. Leigh, and A.J. Miller. 1996. Potassium homeostasis in vacuolate plant cells. Proc. Natl. Acad. Sci. USA 93:10510-10514.

Wells, M.L. 2009. Pecan nutrient element status and orchard soil fertility in the southeastern coastal plain of the United States. HortTechnology 19:432-438.

Wu, J., Z. Wang, Z. Shi, S. Zhang, R. Ming, S. Zhu, M.A. Khan, S. Tao, S.S. Korban, H. Wang, N.J. Chen, T. Nishio, X. Xu, L. Cong, K.J. Qi, X.S. Huang, Y.T. Wang, X. Zhao, J.Y. Wu, C. Deng, C.Y. Gou, W.L. Zhou, H. Yin, G.H. Qin, Y.H. Sha, Y. Tao, H. Chen, Y.N. Yang, Y. Song, D.L. Zhan, J. Wang, L.T. Li, M.S. Dai, C. Gu, Y.Z. Wang, D.H. Shi, X.W. Wang, H.P. Zhang, L. Zeng, D.M. Zheng, C.L. Wang, M.S. Chen, G.B. Wang, L. Xie, V. Sovero, S.F. Sha, W.J. Huang, S.J. Zhang, M.Y. Zhang, J.M. Sun, L.L. Xu, Y. Li, X. Liu, Q.S. Li, J.H. Shen, J.Y. Wang, R.E. Paull, J.L. Bennetzen, J. Wang, and S.L. Zhang. 2013. The genome of the pear (Pyrus bretschneideri Rehd.). Genome Res. 23:396-408.

Xu, X.J., Q.Y. Li, X.H. Song, Q.R. Shen, and C.X. Dong. 2012. Dynamic regulation of nitrogen and organic acid metabolism of cherry tomato fruit as affected by different nitrogen forms. Pedosphere $22: 67-78$.

Zörb, C., M. Senbayram, and E. Peiter. 2014. Potassium in agriculture-status and perspectives. J. Plant Physiol. 171:656-669. 